\title{
PRICING STRATEGY FOR QUASI-PUBLIC FOREST TOURISM PARK: A CASE STUDY IN GUNUNG PANCAR FOREST TOURISM PARK, BOGOR INDONESIA
}

\author{
Ricky Avenzora $^{1 *}$, Tutut Sunarminto ${ }^{1}$, Priyono E. Pratiekto ${ }^{1}$ and Ju-Hyoung Lee $^{2}$ \\ ${ }^{1}$ Post Graduate Study on Ecotourism and Environmental Services Management, \\ Dept. of Forest Resources Conservation and Ecotourism, Faculty of Forestry \\ Bogor Agricultural University. Dramaga, Bogor, Indonesia \\ ${ }^{2}$ Department of Forest Resources, University of Yeung-Nam, 214-1 Dae-Dong, South Korea
}

Received: 17 December 2015, Revised: 27 August 2016, Accepted: 20 September 2016

\begin{abstract}
PRICING STRATEGY FOR QUASI-PUBLIC FOREST TOURISM PARK: A CASE STUDY IN GUNUNG PANCAR FOREST TOURISM PARK, BOGOR INDONESIA. The dynamic of 3-parties conflict of interests (investor, local people and government) in having actual income from the nature tourism park business in Indonesia became worse since a "very progressive" Government Regulation on Forestry Related Services Tariff (so called PP 12/2014) was issued. On one hand, everybody agrees to improve the 17 years old tariff regulation of PP 59/1998. On the other hand, the "unclear reason" of the new tariffs in PP 12/2014 has shocked many parties and created many difficulties while implemented. This paper studies visitors' expenditures and their willingness to pay (WTP) for every recreation services scenario by using contingent valuation method (CVM) survey with open-ended eliciting questionnaire instrument. Regarding the characteristic of Gunung Pancar Forest Tourism Park (GPFTP) the method was used to justify a reasonable and eligible ticket pricing strategy at the GPFTP as a quasi-public recreation park. The survey has also specifically addressed the reasonable ticket-price that aligns with the financial assumption of investor's business plan and local people's economic activities. Results of the survey show that the continuum of visitors' WTP is ranging from 3.4 times (as the response to scenario-1) up to 12.7 times (as the response to scenario-5) of the recent ticket price. The WTP of scenario-2, 3 and 4 are ranging from 4.7, 6.2 and 7.5 times, respectively. Furthermore, the results of Tobit Regression Analysis show that seven important variables are positively correlated, while six variables are negatively correlated with the WTP.
\end{abstract}

Keywords: Tourism Park, contingent valuation method, willingness to pay, ticket pricing

STRATEGI PENETAPAN HARGA UNTUK TAMAN WISATA ALAM QUASI-PUBLIK: STUDI KASUS DI TAMAN WISATA ALAM GUNUNG PANCAR, BOGOR INDONESLA. Dinamika konflik kepentingan tiga pibak (pemodal, masyarakat lokal dan pemerintah) dalam meraib pemasukan aktual dari bisnis taman wisata alam di Indonesia semakin memburuk sejak diberlakukannya Peraturan Pemerintah Nomor 12 Tabun 2014 tentang Jenis dan Tarif Penerimaan Negara Bukan Pajak yang berlaku pada Kementerian Kehutanan (PP 12 /14) yang bersifat "sangat progresif". Pada satu sisi, semua pibak sepakat untuk memperbaiki regulasi tarif dalam PP 59/1998 yang sudah berumur lebih dari 17 tahun, di sisi lain "ketidakjelasan" alasan penetapan tarif baru dalam PP 12/2014 meresabkan berbagai pihak serta menimbulkan kesulitan baru ketika diterapkan di lapangan. Tulisan ini mempelajari pola pengeluaran dan nilai kesediaan membayar (willingness to pay/WTP) pengunjung dalam setiap skenario pelayanan rekreasi menggunakan metode survei valuasi kontingen dengan instrumen kuesioner elisitasi berpola terbuka. Berdasarkan karakteristik. Taman Wisata Alam Gunung Pancar (TWAGP), metode tersebut digunakan untuk. menjastifikasi strategi penetapan harga tiket yang pantas di TWAGP sebagai taman wisata alam yang memiliki karakter quasi-publik. Survey WTP secara spesifik, juga diarabkan untuk. menemukan barga tiket yang sesuai dengan asumsi kelayakan finansial dari rencana usaba investor dan aktivitas ekonomi masyarakat lokal. Hasil survei menunjukean nilai WTP pengunjung berada pada rentang 3,4 kali (sebagai respon terhadap skenario-1) bingga 12,7 kali (sebagai respon terhadap skenario-5) dari harga

*Corresponding author: avenzora19@yahoo.com 
tiket yang berlaku saat studi dilakukan. Sementara peningkatan WTP yang diperoleh dari Skenario-2, 3 dan 4 masingmasing adalah sebesar 4,7 kali, 6,2 kali, dan 7,5 kali. Analisis lebih lanjut menggunakan Regresi Tobit menunjukkan terdapat 7 peubah penting yang berpengaruh positif terbadap nilai WTP, dan 6 peubah penting yang berpengarub negatif terbadap nilai WTP.

Kata kunci: Taman Wisata Alam, metode valuasi kontingen, kesediaan membayar, harga tiket

\section{INTRODUCTION}

Ticket pricing strategy on a quasi-public tourism forest area (QPTFA) in Indonesia has become an important issue for the investor in tourism facilities and services provider, and become a crucial problem between any parties which has interest to gain any benefit from a tourism forest area. The term "quasi-public forest tourism area" in this paper is defined as a tourism forest area that is owned by the government, but its management and utilization are done cooperatively with private parties as investors.

Historically, the cheap ticket price which was applied in QPTFA since the beginning of 1980s until 2014 can be inferred as a burden of government position on providing recreation services for the inhabitants. In fact, the government undeniably has public service obligation to provide recreation service for its citizen (Krauss, 1998)) but the inappropriate understanding and implementation of its obligations have caused losses and conflicts.

Before the 1998 economic crisis and political reform, the important dynamics of loss and conflicts on QPTFA in Indonesia included: (a) the damage of resources and tourism objects caused by government's low ability to provide maintenance and security funds; (b) the low economic benefits gained by local people since they were less-involved in any forest tourism activities; (c) ecological impacts; and (d) several social impacts like demonstration effect and inflation effect (Pizam, 1978; Mathieson \& Wall, 1982 ).

After the political reform, the government issued Government Regulation No. 59 of 1998 (PP 59/1998), which has significantly increased local people's participation in utilizing and managing tourism forest areas. But, several losses and conflicts are still remained, such as: (a) degradation of tourism resources and ecology-fragmentation caused by local people's economic activities; (b) decrease of visitors' satisfaction caused by multi-ticketing dynamics that was applied by local people in their village area surrounding a QPTFA; and (c) the increase of exploitation in pristine area by the ownership of Nature Tourism Business Concession (locally so called Irin Pengusahaan Pariwisata Alam - IPPA). Previously, the concession duration of IPPA was maximum 20 years but it has been changed to maximum 55 years.

Indonesia has abundance resources for the potential supply of QPTFA. Up to now, Indonesia has around 51 National Parks, 221 Nature Reserves, 75 Wildlife Sanctuaries, 116 Quasi-Public Forest Tourism Parks (Taman Wisata Alam), 163 State-Owned Forestry Enterprise Tourism Parks (Wana Wisata) which is a kind of forest tourism park in Java Island managed by the state-owned forestry enterprise (Perum Perbutani), 24 Provincial Forest Parks (Taman Hutan Raya), 12 Game Hunting Forest Parks and more than 1,000 attraction points of nature tourism objects in the protected forest areas that are well distributed throughout the country (Supriyanto \& Sari, 2013).

On one hand, all of those tourism resources on the public forest areas have good potentials to be brought to a supply position by granting thousands of IPPA to the credible investors. However, up to now the government still cannot find a proper strategy to create better benefit from these resources since there are still less than 50 IPPA granted to investors (Supriyanto 
\& Sari, 2013). On the other hand, investors are factually not willing to invest in tourism facilities and services in their IPPA area. After getting the IPPA, generally IPPA-holder tends to only build "low quality" recreation facilities and services; arguing that they are still waiting for the government to provide basic infrastructure as feasibility prerequisite for making bigger investment.

The "low" quality of recreation facilities and services makes the dynamics of the business trapped inside low budget tourism activities. Those dynamics do not only decrease the investors' income, but also damage the recreation area caused by visitors and 'street vendor' activities who keep 'invading' the business activities surrounding the attraction points. Another case can also be found in the study of Ekayani, Nuva, Yasmin, Shaffitri and Tampubolon (2014) which state that the dynamics of low budget tourism activities in Gunung Halimun-Salak National Park tend to be exploited through free rider patterns by the local people for the sake of, and benefits to the locals themselves; without giving significant contribution to the conservation of the resources.

The dynamics of "low-budget tourism activities" lead to low taxes and incomes gained by the government. Consequently, government's ability to fund basic infrastructure development cannot be improved; as well as the funding of the maintenance.

In order to alleviate the above serious "domino effect", Indonesian Government has issued Government Regulation about Items and Tariff of Non-Taxes Income on Forestry Sector (PP 12/2014). The basic goal of this policy is to encourage an ideal and rational condition in developing a QPTFA; however the startling increased price of the tariff components-which has significantly risen by $50-8,000 \%$ times from the previously regulated tariff in PP 59/1998 has concerned many parties. In many ways, the tariff should have been concluded objectively as "not reasonable"; especially in terms of the binding of a space on providing any recreation resources/attractions for the visitors.

The disputation in determining the new tariff has never been solved since many parties are egocentric. On one side, the entrepreneurs (investors, tour operators and tourism service providers) are generally disagreeing with the new tariff. On the other side, the government is still hesitant, and unsure, thus the government is unable to properly implement the policy.

Considering these foregoing dynamics, a study of ticket pricing strategy in a QPTFA is important to be conducted. At the national level, this study is very important for an objective evaluation of the tariff system organized by the government. From the international perspective, this study will be a fundamental support to facilitate high interests of foreign investors to invest in Indonesian forests; such as the investment projects arranged by South Koreans in West Java and Lombok.

The main objectives of this study are: (1) to investigate customers' motive for visiting the vocal point, and (2) to investigate customers' purchasing power in consuming nature tourism services. These two objectives will be described through the value of their Willingness To Pay (WTP) and any other underlying factors.

The W'TP becomes a reference of expenditure (money) that is willingly spent by the consumers to get benefits, including different quantity and better environment quality (Stern, 2000; Baysan, 2001; Zenginobuz, 2002; Uyarra, 2005; Togridou, Hovardas, \& Pantis 2006; Budeanu, 2007; Gosken, Adaman, Ku \& Chen, 2013; Nowacki, 2013; Ekayani \& Nuva, 2013). Moreover, it is convinced by Pagiola, Agostini, Gobbi, de Haan, and Ibrahim (2004) that the concept of Payment for Ecosystem Services (PES) endorses the right of stakeholders in managing the sustainability of recreational resources that have to be fulfilled. The value of WTP can then be used to improve the economic aspects of the tourism management of the tourism without abandoning the aspects of consumer's satisfaction. This becomes important due to the role of nature and environment resources as a non-market 
public commodity, yet the money spent by the customers to get tourism access will certainly become a burden to their satisfaction (utilities).

The Gunung Pancar Forest Tourism Park (GPFTP) was chosen as the research site since it has management complexities, i.e. between "private good" and "public good". Therefore, the tourism service in this site should be classified as a quasi-public resource. One important characteristic of quasi-public forest tourism services in GPFTP involves the facilities of tourism services provided by a private party (PT. Wana Wisata Indah/WWI) through the IPPA. Therefore, it has the characteristic of clear property authority which can be handed over as "private commodity". However, another characteristic entails the attributes of the natural resources and environment in GPFTP which should be categorized as "public commodity", which cannot be aggregately separated in providing supply of nature resources..

For that reason, as "private commodity", the investment products of PT. WWI have rivalry and excludability characteristics. While as "public commodity", the forest area of GPFTP is owned by the government having obligation to fulfill people's needs of recreation; so it also has non-excludability and non-rivalry characteristics.

\section{MATERIAL AND METHOD}

\section{A. Study Design}

Visitors' WTP was measured through stated preference survey using Contingent Valuation Method (CVM). The CVM method (Bowen, 1943) is carried out through three main stages as proposed by Pearce, Atkinson and Mourato (2006) including:

(1) Identifying commodities and services that will be evaluated. The valuation aspects were limited into the condition of facilitates and tourism service in the utilization zone of GPFTP, which has been developed by PT. WWI.

(2) Constructing a hypothetical scenario. Five hypothetical scenarios were arranged gradually based on the review of any documents of the GPFTPs' development plans. The five scenarios were shown to visitors, so each of them could be measured explicitly through the most appropriate ticket price (Table 1).

(3) Eliciting the monetary value. Open-ended questions were used to elicit information regarding visitor's WTP; with intention to let them being honest in answering, and avoiding so called warm glow phenomena. In the warm glow phenomena the respondents are assumed to give answers that just please the interviewer by giving/showing agreement as found in dichotomous choice elicitation method (Andreoni, 1990; Bennett \& Blaney, 2005).

Referring to the price theory of Kahneman, Knetsch and Thaler (1986), it can be justified that the price printed on the ticket has an important role as a strong internal reference price for visitors to give properly and rationally assessment toward "new ticket price". Therefore the "old ticket price" can be a proxy to avoid negative bottom limit of WTP values.

Considering those mentioned references,

Table 1. Hypothetic scenarios for GPFTP

\begin{tabular}{|c|c|}
\hline Scenario & Benefits for visitors \\
\hline 1 & $\begin{array}{l}\text { Renovation and addition of only general facilities (including roads, clean water, toilet, praying room, } \\
\text { bench and shelter) }\end{array}$ \\
\hline 2 & $\begin{array}{l}\text { Scenario } 1 \text { plus addition of board sign, information board, symbols, signs and labels of tourism } \\
\text { attractiveness interpretation in the whole forest areas }\end{array}$ \\
\hline 3 & Scenario 2 plus addition of extra food stall/cafeteria facilities in the areas of camping grounds \\
\hline 4 & Scenario 3 plus addition of extra free playing ground for children in the family picnic areas \\
\hline 5 & Scenario 4 plus addition of free access to outbound and flying fox areas \\
\hline
\end{tabular}


this study used open-ended questions through Tobit Censored Regression Analysis (Tobin, 1958) instead of common Ordinary Least Square (OLS) Regression. The proxy of printed price on the old ticket indicated that the limit values of WTP would be an estimation method that may cause an inconsistent and biased parameter presumption.

The regression model of Tobit utilizes the maximum technique to provide a consistent and not biased parameter presumption. An application of Tobit model in estimating dependent variable $(y)$ in form of WTP values toward "new ticket price" of the GPFTP that is above IDR 2,000 can be specified in the following equations of the latent $\mathrm{y}^{*}$ variable:

If $y^{*}=X \beta+\mathrm{e}>2000$, then $y=X B+e$

If $y^{*}=X \beta+\mathrm{e} \leq 2000$, then $y=0$

where $X \beta$ is scalar of independent variable $X$ multiplied by the appropriate Tobit coefficient of $\beta$, and $e$ is normally distributed error.

The Tobit Formula for expected value of independent variable for every case $(E y)$ is formulated in Equation 3:

$E y=[X \beta \times F(X \beta / \sigma)]+[\sigma \times f(X \beta / \sigma)]$

where $X \beta$ is defined in Eq.1; $\mathrm{F}(X \beta / \sigma)$ as cumulative normal distribution function; $\mathrm{f}(X \beta / \sigma)$ as normal density function; and $\sigma$ as standard deviation of the error (Wagner, $\mathrm{Hu} \&$ Duenas, 2000). In other words, the regression coefficient of Tobit Equation Model is corrected, and the possible W'TP values will be above IDR 2,000.

The influencing factors of WTP values used as variables for the Tobit regression analysis toward WTP values in each scenario are presented in Table 2 . These variables are in line with the theoretical framework formulated by Ramdan and Mohamed (2014) and research into relationship between environment literacy and WTP (Togridou, 2006; Wang \& Jia, 2012; Szell \& Hallett, 2013), that demographic variables are corresponding with personal value aspects and individual environment literacy, like motivation, sensitivity and concern toward environment condition. These aspects provide significant influence toward WTP and individual tendency to act.

The values gained from the survey were then analyzed by using profit-loss and company cash-flow approaches to find out the financial implementation feasibility. The ticket price resulted from this study was developed based on WTP assessment that fulfill the assumption of financial feasibility.

Table 2. Regression variables

\begin{tabular}{ll}
\hline \multicolumn{1}{c}{ Variables } & \multicolumn{1}{c}{ Explanation } \\
\hline DAY & Visiting days; $1=$ weekend (Saturday and Sunday), $0=$ weekdays (Monday-Friday) \\
SEX & Sex; $1=$ male, $0=$ female \\
MARITAL & Marital status; $1=$ married, $0=$ not married \\
AGE & Age, stated in years old \\
EDU & Educational background, stated in the years spent at formal education \\
HOUSEHN & Number of dependents, stated in number of person \\
INCOME & Monthly income, stated in Indonesian Rupiah (IDR) \\
KNOW & Owned information and promotion \\
TVISIT & Total number of visits made to the GPFRP \\
COSTS & Expenditure per one visit to the GPFRP, stated in IDR \\
TRIPL & Time needed to reach the GPFRP, stated in hours \\
MOTIV & Motivation to visit; stated in extended Likert Scale; $1=$ very low, 7= very high \\
CPERF & The assessment towards leisure activities performance in the GPFRP, in extended Likert Scale; \\
& 1= very disappointing to 7= very satisfying (Avenzora, 2008) \\
\hline
\end{tabular}




\section{B. Sample and Data Collection}

The WTP survey of entrance ticket to the GPFTP was conducted between May-August 2014 through direct survey of weekday and weekend visitors. Considering the research results conducted by Batubara (2013) and Kristinawanti (2014) in the GPFTP, the number of respondents was decided to be properly represented by 30 weekday visitors and 100 weekend visitors; as there were different significant numbers between weekdays and weekend visitors.

The questionnaire used in this survey consisted of four parts, namely A, B, C and D. In Part $A$, the questions were intended to get information of visitors' personal background. In Part B, the questions were used to grab visitors' motivation and their perception towards recreation activities and current environment condition in the GPFTP. Questions on motivation and perception were presented in close-ended pattern using Likert-scale, which was extended into 7 scales (Avenzora, 2008); since the Indonesian people always have a detailed terminology in expressing values therefore it was important to extend the Likert-scale from 1-5 to 1-7.

In Part $C$, the respondents were asked about their expenditure in every phase of tourism activities and also about their satisfaction after spending some money. More detailed information was asked in Part D, which were addressed to answer the main research question proposed in this study concerning the visitors' willingness to pay in terms of entrance ticket toward five hypothetical scenarios of the GPFTP development.

\section{RESULT AND DISCUSSION}

\section{A. Characteristic of Study Area}

The GPFTP is situated in the administrative area of Karang Tengah Village, Babakan Madang Sub District, Bogor Regency. This area is located in the working area of the Balai Besar Konservasi Sumber Daya Alam of West Java (BKSDA; a Primer Regional Office of Nature
Conservation under the Ministry of Forestry). According to the Minister of Forestry Decree No. 156/Kpts-II/1988 of 21 March 1988, the total area of this tourism park is $447.50 \mathrm{Ha}$.

The forest coverage is dominated by Pinus merkusii, Falcataria mollucana, Maesopsis eminii, and Shorea spp., which were planted in 1982-1983. The vegetation of nature forest ( \pm 15 hectare) can be found on the slopes of Pancar Mountain. It consists of Altingia excelsa, Quercus spp., Schima walichii, Castanopsis argentea, Podocarpus imbricatus and liana. Wild animals can also be found in this area, such as Macaca fascicularis, Trachypithecus auratus and Sus scrofa.

The area of GPFTP is located $300-800$ meters above sea level (masl), with the height top of Pancar Mountain at 800 masl. The topography varies from slightly slope to very steep slope with $8-80 \%$ tilt. The slope in the south east area (Pancar Mountain) and east area (Pasir Astana Hill) is above 25\%, while the slope in the north and west is about $8-25 \%$.

The main attraction of the GPFTP includes some natural hot springs that have been developed for health tourism activities. It also provides a wide natural mountainous view of pine forest, which creates a freshening and comfortable ambience for the visitors.

The concession of nature tourism in GPFTP is held by PT. Wana Wisata Indah (WWI); the IPPA was granted through The Decree of Forestry Minister No. 54/Kpts-II/1993. Some of the major outdoor recreation activities provided by the PT. WWI are gathering, camping, biking, jogging, hiking, outbound and horse-riding. PT. WWI provides facilities such as a challenging international-standard track for downhill mountain bike, camping ground and a function-hall.

\section{B. Visitor Profile and Visiting Pattern}

Referring to the proportion of their employment, monthly income and age classes; the visitors of GPFTP can be classified as middle-class society in productive age (Table 3 ). This middle-class society is one of the largest market segments in Indonesia with a total 
Table 3. Dominant characteristics of respondents

\begin{tabular}{|c|c|c|}
\hline Characteristic & Weekday visitor (\%) & Weekend visitor $(\%)$ \\
\hline \multicolumn{3}{|l|}{ Sex } \\
\hline Male & 77 & 60 \\
\hline Female & 23 & 40 \\
\hline \multicolumn{3}{|l|}{ Age (years) } \\
\hline $10-19$ & 23 & 22 \\
\hline $20-29$ & 43 & 36 \\
\hline $30-39$ & 17 & 16 \\
\hline $40-49$ & 4 & 23 \\
\hline$>50$ & 13 & 3 \\
\hline \multicolumn{3}{|l|}{ Marital Status } \\
\hline Single & 63 & 52 \\
\hline Married & 37 & 47 \\
\hline Widowed/divorced & 0 & 1 \\
\hline \multicolumn{3}{|l|}{ Education } \\
\hline Junior High School & - & 6 \\
\hline Senior High School & 70 & 47 \\
\hline Vocational Diploma & 23 & 10 \\
\hline University Degree & 7 & 35 \\
\hline Others & - & 2 \\
\hline \multicolumn{3}{|l|}{ Occupation } \\
\hline Student & 23 & 24 \\
\hline Civil Public Servant & 7 & 8 \\
\hline Private Employees & 37 & 48 \\
\hline Self employed & 30 & 13 \\
\hline Housewife & 3 & 7 \\
\hline \multicolumn{3}{|l|}{ Monthly Income } \\
\hline Not answered & - & 1 \\
\hline$<$ IDR 1 million & 30 & 26 \\
\hline IDR 1-4 million & 50 & 41 \\
\hline IDR 4,1-10 million & 13 & 22 \\
\hline > IDR 10 million & 7 & 10 \\
\hline \multicolumn{3}{|l|}{ Home Area } \\
\hline Jakarta & 33 & 22 \\
\hline City of Bogor & 10 & 6 \\
\hline Municipality of Bogor & 33 & 34 \\
\hline Bekasi Regency & 20 & 21 \\
\hline Depok City & 3 & 11 \\
\hline Others & 1 & 6 \\
\hline
\end{tabular}

number of about 99 million in 2009 and shared around $43 \%$ of the total national household consumption (Nizar, 2015). Furthermore, Nizar (2015) also stated that this middle class contributed positively to the economic development because it created demand for high quality consumption commodities with increasing returns to scale. Therefore, it is obvious that GPFTP has big market potential and able to provide continuity assurance demanded in the future.

Table 4 shows that individual visitors comprised the biggest portion from the total visits; and reached $57 \%$ during the weekdays and $40 \%$ during the weekend. Then, it was followed by family visitors, which reached $30 \%$ during 
Table 4. The dominant visiting pattern of GPFTP

\begin{tabular}{lcc}
\hline \multicolumn{1}{c}{ Characteristic of Visit } & Weekday visitor (\%) & Weekend visitor (\%) \\
\hline Category of visitors & & \\
$\quad$ Teenagers individual & 27 & 15 \\
$\quad$ Adult individual & 30 & 25 \\
$\quad$ Family & 30 & 36 \\
$\quad$ Group/organization & 13 & 24 \\
Pattern of visit & & \\
$\quad$ Independent tour & 87 & 76 \\
$\quad$ Guided tour & 13 & 24 \\
Staying overnight & & 86 \\
$\quad$ No & 90 & 14 \\
$\quad$ Yes & 10 & 35 \\
Time length of knowing the object & & 35 \\
$\quad<1$ year & 27 & 30 \\
1-3 year(s) & 20 & 47 \\
$\quad 3$ years & 53 & 53 \\
First-time visit & & \\
$\quad$ Yes & 27 & \\
$\quad$ No & 73 & \\
\hline
\end{tabular}

the weekdays and $36 \%$ during the weekend.

Most visitors of GPFTP only took a short trip, approximately four hours per visit. The number of visitors who stayed overnight was less than $15 \%$ from the total number of visits, both during weekdays and weekend. The average duration of overnight stay was mostly two days and one night. This short duration of trips was also strongly predicted and was caused by limited lodging facilities provided by management in the camping ground areas.

The average total number of visits (since the beginning) was 5 times among weekday visitors and 4 times among weekend visitors. Moreover, the number of visits during the last past year were 3 times among weekday visitors and 2 times among weekend visitors. The finding shows that GPFTP visitors have a positive trend to repeatedly visit the object.

\section{Motive and Perception of Visitor}

The respondents' visit was triggered by their motives to escape from routines and to enjoy beautiful scenery for hunting photography (Figure 1). They stated that the area of GPFTP is beautiful and natural; it provides freshening ambience and panorama to indulge their physical and mind relaxation and refreshment.

The beauty of the area formed by pine stands, rocky mountains and mountainous landscape motivated the visitors to take photos and display them in various social media. The presence of esthetic pine stands also became the main attraction for the tourists. It was strongly related with the purpose of their visits to make movie, photos for memory album, pre-wedding photos; and even for individuals, education, research, and commercial interests or needs.

Other dominant motives were the encouragement to have family picnic and to attend community gathering; with specific intention to improve the quality of family bonds. The same reasons came from the community groups who wanted to maintain the quality of their relationship and cooperation between groups and/or organizations. The difference was created in the way they arranged the meeting; the community/groups usually created a varied and programmed educational tour and training, compared to family or acquaintance meetings. 


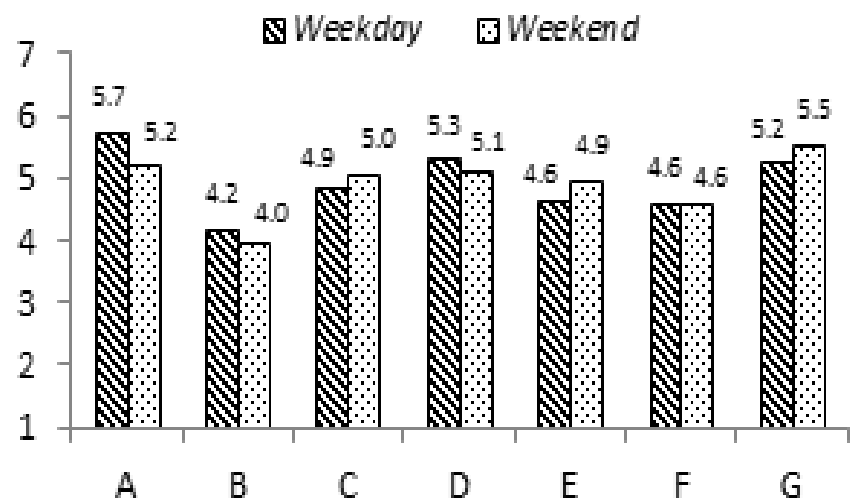

Remarks:

Figure 1. Number of visit according to their motives to visit GPFTP

$\mathrm{A}=$ Outdoor recreation; $\mathrm{B}=$ Sports and wellness; $\mathrm{C}=$ Family picnic; $\mathrm{D}=$ Group/community gathering;

$\mathrm{E}=$ Education/knowledge; $\mathrm{F}=$ Special hobby/interest; $\mathrm{G}=$ Photo hunting; $1=$ Very Low; $2=$ Low; $3=$ Rather low;

$4=$ Moderate; $5=$ Rather high; $6=$ High; $7=$ Very high

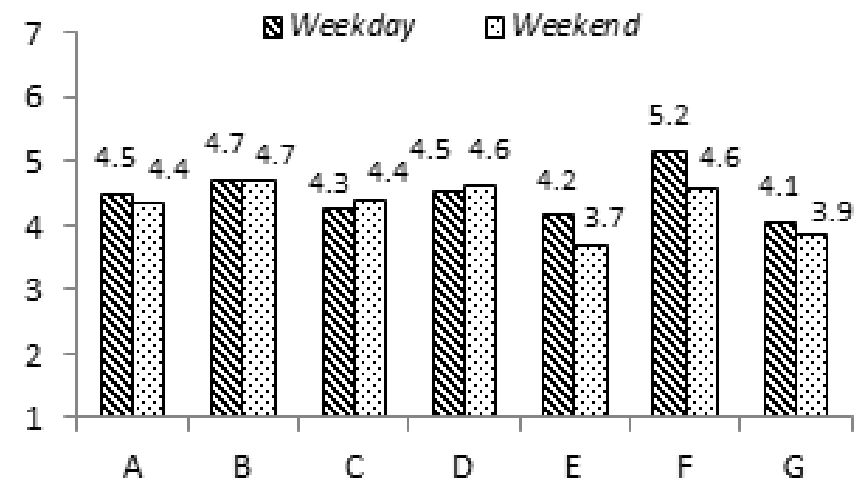

Figure 2. Number of visits according to factors that attracts visit to GPFTP

Remarks:

$\mathrm{A}=$ Diversity of tourism potentials; $\mathrm{B}=$ Costs and fare $\mathrm{C}=$ Visitor crowdness; $\mathrm{D}=$ Accessibility; $\mathrm{E}=$ Facilities and services; $\mathrm{F}=$ Cleanliness and comfort; $\mathrm{G}=$ Information and promotion; $1=$ Very Low; $2=$ Low; $3=$ Rather low; 4= Moderate; $5=$ Rather high; $6=$ High; $7=$ Very high

Figure 2 shows the highest rated GPFTP attractions including cleanliness and comfort of the area, affordable cost and fare, and easy access to reach the forest park. However, the provision of varies tourism attractions did not become the main factor that attracted visitors. The other important factors, which are directly linked to the management performance such as facility, services and promotion, got the lowest scores in this survey.

Weekday visitors gave higher scores towards any kinds of recreation activities in GPFTP compared to weekend visitors (Figure 3). The activities that are directly linked to natural ambience, such as sightseeing, enjoying coolness and taking photographs, provide the highest satisfaction to the visitors. However, some visitors rated "somewhat disappointed" towards wildlife watching activities, since wild animals were difficult to encounter.

Improving environment condition and facilities becomes a challenge for PT. WWI. Figure 4 shows that generally visitors were not 'satisfied' with the environment conditions and facilities. Visitors were generally quite satisfied with the cleanliness and the beauty of the areas. However, there was still lack of basic cleanliness facilities, like trash bins which were mentioned by visitors as one area that need improvement. Furthermore, the bad road condition might 


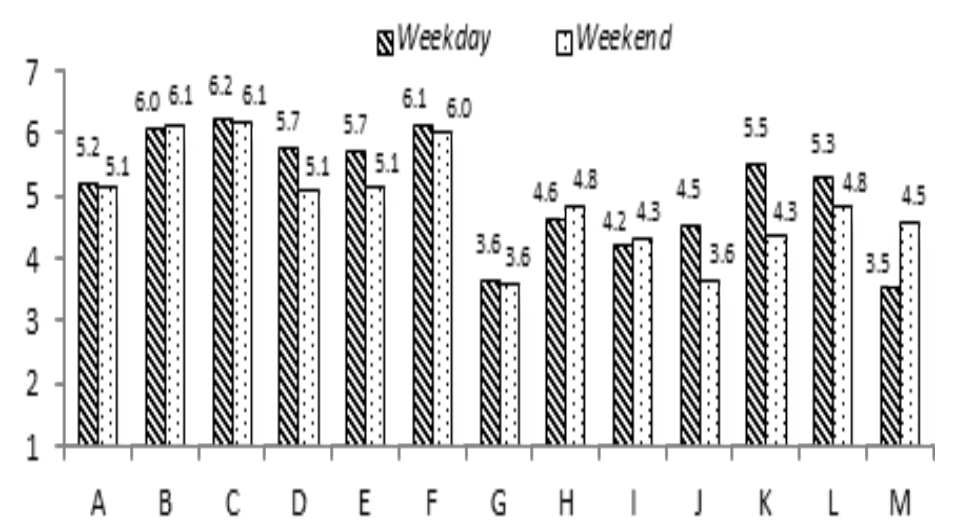

Remarks:

Figure 3. Rating of recreational activities

$\mathrm{A}=$ Picnic; $\mathrm{B}=$ Sightseeing; $\mathrm{C}=$ Enjoying coolness; $\mathrm{D}=$ Camping; $\mathrm{E}=$ Mountain biking; $\mathrm{F}=$ Photo taking;

$\mathrm{G}=$ Wildlife watching; $\mathrm{H}=$ Flora observation; $\mathrm{I}=$ Hot-water bathing; $\mathrm{J}=$ Horse riding; $\mathrm{K}=$ Tracking\& climbing;

$\mathrm{L}=$ Gathering; $\mathrm{M}=$ Outbound; $1=$ Very Low; $2=$ Low; $3=$ Ratherlow; $4=$ Moderate; $5=$ Rather high; $6=$ High;

$7=$ Very high

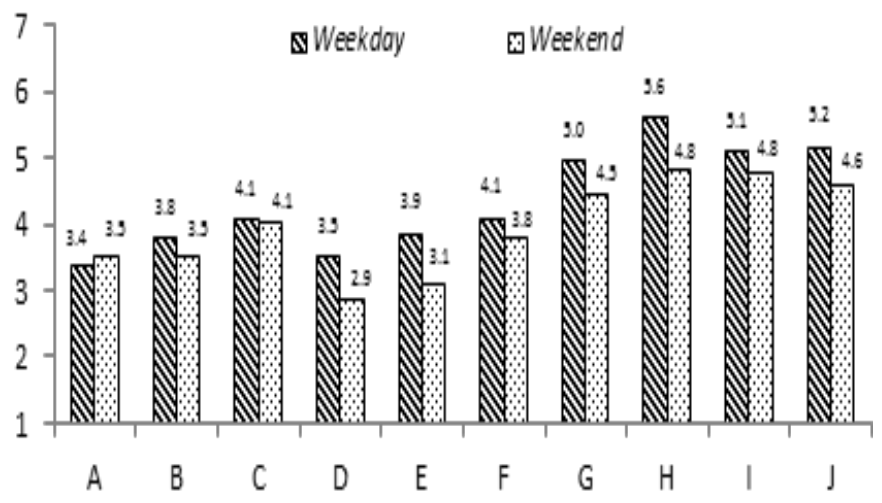

Figure 4. Perception towards environment condition and facilities

Remarks:

$\mathrm{A}=$ Road access $\mathrm{B}=$ Parking area $\mathrm{C}=$ Recreational facilities; $\mathrm{D}=$ Trash \& sanitation facilities;

$\mathrm{E}=$ Telecommunication network; $\mathrm{F}=$ Information \& service center; $\mathrm{G}=$ Security; $\mathrm{H}=$ Green \& cleanliness;

$\mathrm{I}=$ Attitude of the local community; J= Staff's' performance; $1=$ Very Low; $2=$ Low; $3=$ Ratherlow; 4= Moderate;

$5=$ Rather high; $6=$ High; $7=$ Very high

lead to lessening visitors' satisfaction "on travel phase"; while the visitors perceived that this tourism area is a strategic and accessible place.

\section{Expenditure and Satisfaction}

The average expenditure of a weekday visitor was IDR 100,142 and of a weekend visitor was IDR 103,624. Those expenditures were mostly spent for transportation and food; otherwise, the average expenditures on some specific items, like tourism facilities and services, accommodation, souvenir or hot spring services were aggregately low (Figure 5).

Furthermore, most of visitors' expenditure was spent during departing to the site and on returning home phases (Figure 6). The relatively low expenditure at "on site activities" is not just an important indicator of middle-low visitor's budget, but also as a result of uncreative supply of touristic goods and services; such as proper food, drink and even souvenirs.

The visitors' satisfaction towards trip expenditure in each phase is perceived "fair". It indicates that the visitors of GPFTP consider 


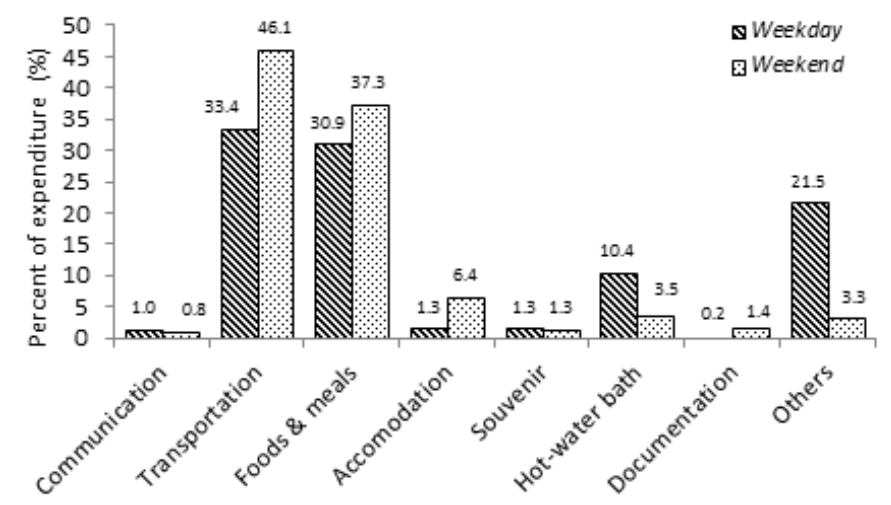

Figure 5. The expenditure proportion of GPFTP visitors based on expenditure items

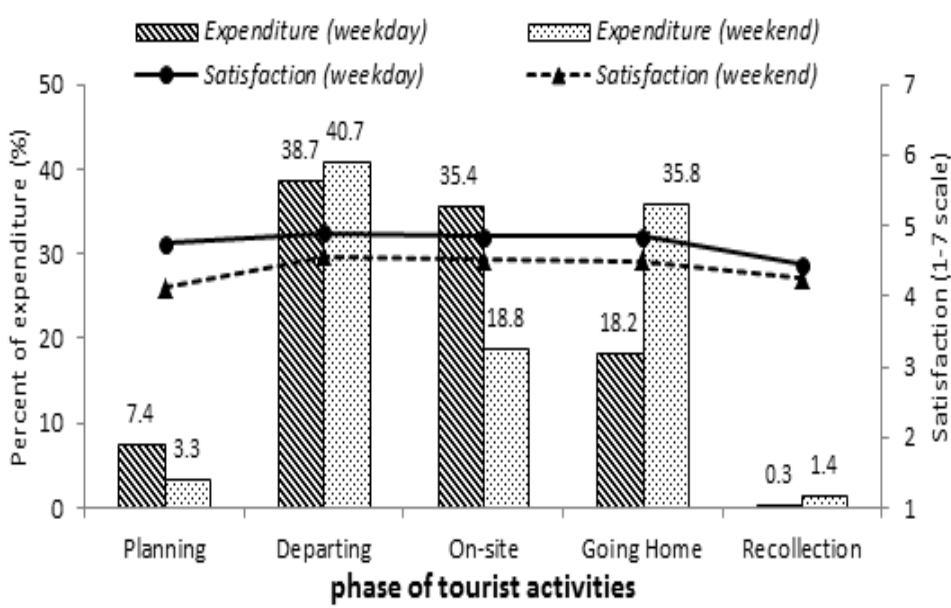

Figure 6. The proportion and satisfaction level of visitors' expenditure based on the phase of tourist activities

the expenditure amount is reasonable so that visitor satisfaction towards tourism expenditure does not give significant influence toward the satisfaction of the whole trip. Therefore it is still possible to increase the tariff of tourism services in optimizing the buying ability.

\section{E. WTP Estimation}

Table 5 presents the estimation values of WTP with five scenarios of facility and service development in the GPFTP. All respondents were willing to pay the same or higher than that of the entrance ticket, which is IDR 2,000 as regulated in the PP 59/1998; as the internal reference price that was still applied when the survey was conducted.

There is a quite significant difference between WTP values in each scenario. In other words, respondents are willing to pay more expensive ticket if they got better and more complete facilities and services. It indicates that the visitors show their utilitarian aspects by considering prices, benefits and other attributes in assessing tourism service.

This result of WTP that arises from utilitarian consideration is logically accepted, since tourism services in the GPFTP is a wellknown quasi-public and can be compared with other nature tourism objects in the same markets. It is different with any case on public and non-market commodities, since the contingent, where the contingent assessment towards public commodities and services are made based on the consideration of moral satisfaction to contribute toward the preservation of commodities or public 
Table 5. The WTP estimation on five scenarios of development on the GPFTP

\begin{tabular}{|c|c|c|c|c|c|c|c|c|}
\hline WTP Est. & Mean $^{a}$ & LB Mean ${ }^{b}$ & UB Mean $^{c}$ & Median & SD & Min. & Max. & $\left(\mathrm{Q}_{3}-\mathrm{Q}_{1}\right)^{\mathrm{d}}$ \\
\hline \multicolumn{9}{|l|}{ Scenario $1^{\mathrm{e}}$} \\
\hline Weekday & $8,266.7$ & $7,065.9$ & $9,467.4$ & 10,000 & $3,215.6$ & 5,000 & 20,000 & 5,000 \\
\hline Weekend & $6,405.0$ & $5,655.0$ & $7,155.0$ & 5,000 & $3,779.7$ & 2,000 & 20,000 & 3,000 \\
\hline Overall & $6,834.6$ & $6,187.5$ & $7,481.8$ & 5,000 & $3,729.4$ & 2,000 & 20,000 & 5,000 \\
\hline \multicolumn{9}{|l|}{ Scenario 2} \\
\hline Weekday & $11,716.7$ & $9,964.8$ & $13,468.6$ & 10,000 & $4,691.7$ & 5,000 & 25,000 & 7,000 \\
\hline Weekend & $8,825.0$ & $7,924.9$ & $9,725.1$ & 10,000 & $4,536.3$ & 3,000 & 25,000 & 5,000 \\
\hline Overall & $9,492.3$ & $8,674.0$ & $10,310.6$ & 10,000 & $4,715.5$ & 3,000 & 25,000 & 5,000 \\
\hline \multicolumn{9}{|l|}{ Scenario 3} \\
\hline Weekday & $13,733.3$ & $11,984.2$ & $15,482.5$ & 12,250 & $4,684.4$ & 7,500 & 25,000 & 5,500 \\
\hline Weekend & $12,130.0$ & $10,437.9$ & $13,822.1$ & 10,000 & $8,527.9$ & 3,000 & 50,000 & 8,000 \\
\hline Overall & $12,500.0$ & $11,142.4$ & $13,857.6$ & 10,000 & $7,823.4$ & 3,000 & 50,000 & 6,250 \\
\hline \multicolumn{9}{|l|}{ Scenario 4} \\
\hline Weekday & $15,666.7$ & $13,310.0$ & $18,023.4$ & 15,000 & 6,311.4 & 7,500 & 35,000 & 10,000 \\
\hline Weekend & $14,715.0$ & $12,487.3$ & $16,942.7$ & 10,000 & $11,227.1$ & 3,000 & 70,000 & 8,000 \\
\hline Overall & $14,934.6$ & $13,149.3$ & $16,719.9$ & 12,000 & $10,288.4$ & 3,000 & 70,000 & 8,500 \\
\hline \multicolumn{9}{|l|}{ Scenario 5} \\
\hline Weekday & $30,833.3$ & $21,312.3$ & $40,354.4$ & 25,000 & $25,497.9$ & 10,000 & 150,000 & 10,000 \\
\hline Weekend & $23,715.0$ & $19,209.0$ & $28,221.0$ & 20,000 & $22,709.0$ & 3,000 & 150,000 & 15,000 \\
\hline Overall & $25,357.7$ & $21,284.4$ & $29,430.9$ & 20,000 & $23,473.2$ & 3,000 & 150,000 & 15,500 \\
\hline
\end{tabular}

Remarks:

$\mathrm{a}=$ Mean of stated WTP in Indonesian Rupiah (IDR); $\mathrm{b}=$ Lower-bound mean at $95 \%$ confidence interval; $\mathrm{c}=$ Upper-bound mean at $95 \%$ confidence interval; $\mathrm{d}=$ Interquartile range, $75^{\text {th }}$ percentile minus $25^{\text {th }}$ percentile; $\mathrm{e}=$ See Table 1 for description of each scenario

resources (Kahneman \& Knetsch, 1992; Ajzen \& Driver, 1992).

The data in Table 5 shows that the average WTP gained from weekday visitors is significantly higher compared to the WTP of weekend visitors. The one-way Mann-Whitney test at $95 \%$ confidence interval resulted in each scenario to a conclusion that the weekdays visitors of the GPFTP stated higher WTP compared to weekend/holiday visitors ( $\mathrm{p}$-value $<\alpha=0.05)$.

Above all, the respondents of GPFTP are willing to pay IDR 6,834.6 for entrance ticket for Scenario 1; IDR 9,492.3 for Scenario 2. These two WTP values of Scenario 1 and 2, when being compared with external reference prices (the price entrance ticket in other nature tourism objects), are more-or-less equivalent with the entrance ticket price of Tirta Sanita Hot Spring in Parung District and Ciparay
Hot Spring in Tourism Areas of Gunung Salak Endah, Western Bogor; both are also in Bogor Regency.

In Scenario 3 and 4, the values of willingness to pay were increasing, IDR 12,500 and IDR 14,934.6 or quite equivalent with the entrance ticket to Taman Wisata Matahari (also in Bogor Regency) that is IDR 15,000 . While in Scenario 5, the WTP has jumped to IDR 25,357.7. This value is higher than the entrance ticket of Taman Buah Mekarsari (IDR 25,000 in Cianjur Regency), but still lower than the entrance ticket price of the most popular hot spring Sari Ater in Subang Regency (West Java) that charges IDR 35,000.

\section{F. The WTP Variables}

There are 10 of 13 independent variables that have consistent (always same) regression coefficient in every presumption model of 
Table 6. Analysis result of Tobit model (dependent variable $=$ stated WTP)

\begin{tabular}{lrrrrrrrrrr}
\hline \multirow{2}{*}{ Variables $^{\mathrm{a}}$} & \multicolumn{2}{c}{ Scenario $^{\mathrm{b}}$} & \multicolumn{2}{c}{ Scenario $2^{\mathrm{c}}$} & \multicolumn{2}{c}{ Scenario $3^{\mathrm{d}}$} & \multicolumn{2}{c}{ Scenario $4^{\mathrm{e}}$} & \multicolumn{2}{c}{ Scenario $5^{\mathrm{f}}$} \\
\cline { 2 - 10 } Constant & \multicolumn{1}{c}{ Beta } & \multicolumn{1}{c}{$t$-Stat. } & \multicolumn{1}{c}{ Beta } & \multicolumn{1}{c}{$t$-Stat. } & \multicolumn{1}{c}{ Beta } & $t$-Stat. & \multicolumn{1}{c}{ Beta } & \multicolumn{1}{c}{$t$-Stat. } & \multicolumn{1}{c}{ Beta } & $t$-Stat. \\
\hline DAY & 1194.48 & 0.40 & 9008.81 & $3.27^{* *}$ & 11097.23 & $2.91^{* *}$ & 13860.43 & $2.85^{* *}$ & 21801.57 & $2.28^{* *}$ \\
SEX & -1535.41 & $-1.96^{*}$ & -2733.35 & $-3.56^{* *}$ & -3231.28 & $-3.17^{* *}$ & -3602.22 & $-2.78^{* *}$ & -6737.90 & $-2.63^{* *}$ \\
MARITAL & 798.55 & 1.20 & 342.65 & 0.54 & 78.03 & 0.09 & 340.11 & 0.30 & 4405.47 & $2.02^{* *}$ \\
AGE & -2040.26 & -1.49 & -25.07 & -0.02 & -754.51 & -0.41 & -1756.25 & -0.75 & -8154.59 & $-1.78^{*}$ \\
EDU & -32.78 & -0.73 & -3.78 & -0.09 & -88.20 & -1.52 & -158.16 & $-2.15^{* *}$ & -149.14 & -1.04 \\
HOUSEHN & 81.13 & 0.57 & 30.10 & 0.22 & 53.24 & 0.30 & 215.86 & 0.95 & 159.64 & 0.36 \\
INCOME & 222.06 & 0.63 & -112.42 & -0.32 & 129.12 & 0.27 & 318.30 & 0.52 & 710.01 & 0.59 \\
KNOW & $1.66 \mathrm{E}-04$ & 0.75 & $3.05 \mathrm{E}-05$ & 0.27 & $3.41 \mathrm{E}-04$ & $1.69 *$ & $3.59 \mathrm{E}-04$ & $2.23^{* *}$ & $2.37 \mathrm{E}-04$ & $2.67 * *$ \\
TVISIT & 896.33 & $2.72^{* *}$ & 395.97 & 1.22 & 967.60 & $2.23^{* *}$ & 952.72 & $1.71^{*}$ & 1089.38 & 1.02 \\
COSTS & -62.84 & $-1.68^{*}$ & -45.66 & -1.27 & -67.74 & -1.39 & -89.61 & -1.44 & 217.02 & $1.8^{*}$ \\
TRIPL & $1.91 \mathrm{E}-03$ & 1.57 & $2.24 \mathrm{E}-03$ & $1.95^{* *}$ & $9.53 \mathrm{E}-04$ & 0.60 & $1.37 \mathrm{E}-03$ & 0.68 & $4.16 \mathrm{E}-03$ & 1.05 \\
MOTIV & 146.30 & 0.50 & 412.92 & 1.48 & 279.73 & 0.74 & 218.61 & 0.45 & 858.90 & 0.91 \\
CPERF & 115.20 & 0.22 & 261.22 & 0.51 & 901.15 & 1.30 & 1293.48 & 1.47 & 1036.48 & 0.60 \\
Sigma & 649.22 & 1.16 & -308.55 & -0.58 & -711.50 & -0.98 & -1301.02 & -1.41 & -1227.91 & -0.68 \\
& 3399.68 & & 3200.25 & & 4407.68 & & 5577.57 & & 10920.54 & \\
\hline
\end{tabular}

Remarks:

$\mathrm{a}=$ Please refer to Table 2 for definitions of variables

$\mathrm{b}=$ Tobit model 1; $\mathrm{N}=122 ; 5$ left-censored observations at WTP $<=2000 ; 117$ uncensored observations; 0 rightcensored observations; LR $\chi 2(13)=31.17$; prob $>\chi 2=0.0032$; Log-likelihood $=-1199.1048$; pseudo R2=0.0128

$\mathrm{c}=$ Tobit model 2; $\mathrm{N}=122 ; 0$ left-censored observations at WTP $<=2000 ; 122$ uncensored observations; 0 rightcensored observations; LR $\chi 2(13)=23.47$; prob $>\chi 2=0.0364$; Log-likelihood $=-1157.7707$; pseudo R2 $=0.0100$

$\mathrm{d}=$ Tobit model 3; $\mathrm{N}=126$; 0 left-censored observations at WTP $<=2000 ; 126$ uncensored observations; 0 rightcensored observations; LR $\chi 2(13)=26.71$; prob $>\chi 2=0.0136$; Log-likelihood $=-1236.0653$; pseudo R2 $=0.0107$

$\mathrm{e}=$ Tobit model 4; $\mathrm{N}=124$; 0 left-censored observations at WTP $<=2000 ; 124$ uncensored observations; 0 rightcensored observations; LR $\chi 2(13)=24.08$; prob $>\chi 2=0.0304$; Log-likelihood $=-1245.6354$; pseudo R2 $=0.0096$

$\mathrm{f}=$ Tobit model 5; $\mathrm{N}=124 ; 0$ left-censored observations at WTP $<=2000 ; 124$ uncensored observations; 0 rightcensored observations; LR $\chi 2(13)=28.59$; prob $>\chi 2=0.0075$; Log-likelihood $=-1328.9501$; pseudo R2 $=0.0106$

${ }^{*}=$ significant at $90 \%$ confidence interval; $* *=$ significant at $95 \%$ confidence interval; $\mathrm{LR}=$ likelihood ratio

WTP in the five hypothetical scenarios (Table 6). The remaining three variables, the number of dependents (HOUSEHN) has negative coefficient only in Scenario 2, while in the other scenarios this variable is positive. Next, the total numbers of visit to GPFRP (TVISIT) is negative in all scenario models, except in Scenario 5; while the satisfaction towards leisure activities performance in the GPFRP (CPERF) is always negative except in Scenario 1. The type of visiting days (DAY) is the only independent variable that always gives significant influence to all WTP scenario models; while the educational background (EDU), the number of dependents (HOUSEHN), the time needed to reach the GPFRP (TRIPL), the motivation to visit GPFRP (MOTIV) and the satisfaction towards leisure activities performance in the GPFRP (CPERF) variables do not give significant influences to the five presumption models of WTP.

The result of Tobit regression model (see Table 6) is in line with the result of previous similar researches in several countries (Romsa \& Blenman, 1989; Davis \& Tisdell, 1998; Villalobos-Céspedes, Galdeano-Gómez \& Tolón-Becerra, 2002; Tisdell \& Wilson, 2005; Pouta, Neuvonen \& Sievänen, 2009; Curtin, 2010; Lee, Lee, Kim \& Mjelde, 2010), in which WTP values of visitors toward nature tourism products/services are determined by many factors, i.e. age, sex, education level and income. The education variable that has positive coefficient in the scenario model is considered appropriate; since generally educated visitors have sufficient knowledge and high expectation toward the quality of tourism products/ services. 
Table 7. Ticket price recommendation

\begin{tabular}{crc}
\hline \multirow{2}{*}{ Scenario } & Total Ticket Price (IDR) & Share for Company ${ }^{\mathrm{a}}$ (IDR) \\
\hline 1 & 8,000 & 3,000 \\
2 & 10,000 & 5,000 \\
3 & 12,000 & 7,000 \\
4 & 15,000 & 10,000 \\
5 & 25,000 & 20,000 \\
\hline
\end{tabular}

Remarks:

${ }^{a}$ Company income after being subtracted with non-tax revenue paid to the government

Table 8. Investment analysis

\begin{tabular}{lrrr}
\hline Variable & Scenario 1 & Scenario 2 & Scenario 3 \\
\hline NPV & $715,498,000$ & $2,547,010,000$ & $5,030,956,000$ \\
IRR & $23.10 \%$ & $38.11 \%$ & $83.28 \%$ \\
BCR & 2.17 & 4.00 & 6.48 \\
BEP & Year-10 & Year-5 & Year-3 \\
\hline
\end{tabular}

The insignificant influence of education level is strongly predicted related with the well-educated visitors of the GPFTP. Then, the positive coefficient in income variable is in line with other research results that visitors who have higher income are willing to pay more, while visitors who have lower income are sensitive to price changes, and even reluctant to make some purchases in a premium or high price tour (Eagles \& Cascagnette, 1995; Jang, Morrison \& O'Leary, 2002; Reynisdottir, Song \& Agrusa, 2008). Further, in this study the phenomenon of income sensitivity towards premium price is well described in Scenario 3, 4, and 5 , where the income level has significantly influenced the W'TP. Therefore, the benefits of better service quality are valued higher than that of in Scenario 1 and 2.

The variables of visiting days that significantly influence all five models of WTP can be explained from the visitors' characteristics who visit that day. The "family/outdoor activities seekers" is still the biggest market segment of the GPFTP during weekends/holiday; while "escape/relaxation seekers" are typical visitors on weekdays. The second type of visitors, according to Jang, Morrison, and O'Leary
(2002), has willingness to spend more money to fulfill the needs of environment, knowledge and entertainment; so that weekdays visitors have approximately higher WTP compared to weekend visitors. For that reason, the policy of premium price that are mostly based on "lack of access perspective" in peak visits during holidays, can be considered to be changed into a policy that is based on satisfaction level of service and high quality of amenity perspective during a weekday visit.

The result also indicates a insignificant positive correlation between visit motivation variable toward WTP. It also shows negative correlation between recreation activities performance and environment condition variables-which are similar to the research results conducted by Ajzen and Driver (1992) in Massachusetts, USA. In relation to these results, Ajzen and Driver (1992) stated that the cause is moral consideration toward ticket price and emotional experiences related to activities done in the areas.

Negative correlation between number of visits and performance assessment towards WTP values implies that returning visitors and satisfied visitors tend to be reluctant to pay 
Table 9. The increase of government non-tax revenue tariff due to PP 12 Year 2014

\begin{tabular}{|c|c|c|c|}
\hline Component & "Old" Tariff a (IDR) & "New" Tariff b (IDR) & Increase Rate \\
\hline Foreign Tourist & $15,000.00$ & $100,000.00$ & $567 \%$ \\
\hline Domestic Tourist & $2,000.00$ & $5,000.00$ & $150 \%$ \\
\hline Motorbike & $1,000.00$ & $5,000.00$ & $400 \%$ \\
\hline Car & $1,500.00$ & $10,000.00$ & $567 \%$ \\
\hline Bus/truck & $2,500.00$ & $50,000.00$ & $1,900 \%$ \\
\hline Bicycle & $1,000.00$ & $2,000.00$ & $100 \%$ \\
\hline Horse & $1,000.00$ & $1,500.00$ & $50 \%$ \\
\hline Camping & $5,000.00$ & $5,000.00$ & $0 \%$ \\
\hline Jungle tracking & NA & $2,500.00$ & NA \\
\hline Wildlife-watching & NA & $5,000.00$ & NA \\
\hline Outbound & NA & $75,000.00$ & NA \\
\hline Commercial Video & $1,000,000.00$ & $10,000,000.00$ & $900 \%$ \\
\hline Handycam & $12,500.00$ & $1,000,000.00$ & $7,900 \%$ \\
\hline Photo $^{c}$ & $3,000.00$ & $250,000.00$ & $8,233 \%$ \\
\hline
\end{tabular}

Remarks:

${ }^{\mathrm{a} B}$ Based on PP 59/1998

${ }^{\mathrm{b}}$ Based on PP $12 / 2014$

premium ticket price; this indicates a potential of the so called "free-rider" problems by Baumol (1952); which is often found in public commodities. This should be fully considered by the management, that even though the freeriders are willing to pay additional cost for better service, in fact they might choose other more affordable tourism objects, which might influence the number of visits to GPFTP. In other words, the increase of WTP among freeriders is vague, since it is merely a warm glow impact (Andreoni, 1990; Bennett \& Blaney, 2005).

\section{G. Optional Strategies on Ticket Pricing}

Considering those aforementioned research results, the possible ticket price range is described in Table 7. The recommended price is not exactly the same with the WTP values gained from the study, but it is rounded up to ease the transaction of the nominal value that is included in the statistical confidence interval.

\section{CONCLUSION}

Results that visitors responses toward ticket price changes in the area of a quasi-public forest tourism park tend to be influenced by the following aspects: (a) day of visit; (b) received information and promotion; (c) the income level of visitors; (d) the perception values toward the quality of recreation resources; and (e) the satisfaction level gained by visitors. The satisfaction level of visitors tends to be influenced by the number of visitors. Visitors have higher satisfaction level when there is lower number of visitors, which is expressed through higher WTP to pay entrance ticket.

In terms of objective assessment actually a multi stakeholder investment is reliable to be done which may lead to a communal benefit. However, it needs an integrity, and willingness to be transparent to each other. Therefore, the government regulation to improve the income through increasing the tariff of entrance ticket should not be refused by the entrepreneur of quasi-public tourism forest. The setting of tariff level should consider the principles of equality, appropriateness, sustainability, and multiple economic benefits on regional mindset instead of just focal point only. Concerning all of the above findings, there are several important chances to improve the Government Regulation on Forestry Related Services Tariff (so called PP 12/2014), i.e. the existing tariff for domestic individual visitor can be increased ranging from 1.4 times to 5 times higher than 
the tariff in PP 12/2014.

To gain a more comprehensive and objective description of quasi-public forest recreation services in Indonesia, it is suggested to conduct similar research in other forest tourism parks. Knowing that Indonesia has rich and varies tourism parks, similar research should be conducted in four different types of quasipublic tourism forest areas such as national park, wildlife sanctuary, provincial forest park and forest recreational park.

\section{ACKNOWLEDGEMENT}

A special appreciation is addressed to the Management of PT. Wana Wisata Indah who has openly provided access and supports to facilitate the study.

\section{REFERENCES}

Ajzen, I., \& Driver, B.L. (1992). Contingent value measurement: On the nature and meaning of willingness to pay. Journal of Consumer Psychology, 1(4), 297-316

Andreoni, J. (1990). Impure altruism and donations to public goods: A theory of warm-glow giving. Economic Journal, 100 (401), 464-477.

Avenzora, R. (2008). Penilaian potensi dan obyek wisata: aspek dan indikator penilaian (Tourism objects and potentials evaluation: aspect and indicator of evaluation). In R. Avenzora (eds.), Ekoturisme: Teori dan praktek (pp. 241-278). Jakarta: Badan Rehabilitasi dan Rekonstruksi (BRR) NAD-Nias

Bank Indonesia. (2015). Laporan perekonomian Indonesia 2014. Jakarta: Bank Indonesia

Batubara, R.P. (2013). Strategipemberdayaan masyarakat dalam pembangunan dan pengembangan Taman Wisata Alam Gunung Pancar. Nusa Bangsa University, Bogor.

Baumol, W. (1952). Welfare economics and the theory of the state. Cambridge, MA: Harvard University Press.

Baysan, S. (2001). Perceptions of the environmental impacts of tourism: A comparative study of the attitudes of German, Russian and Turkish tourists in Kemer, Antalya. Tourism Geographies, 3(2), 218-235.

Bennett, R.M., \& Blaney, R.J.P. (2005). Estimating the benefits of farm animal welfare legislation using the contingent valuation method. Agricultural Economics, 29(1), 85-98.

Bowen, H.R. (1943). The interpretation of voting in the allocation of economic resources. Quarterly Journal of Economics, 58, 27-48

Budeanu, A. (2007). Sustainable tourist behaviour? A discussion of opportunities for change. International Journal of Consumer Studies, 31(5), 499-508.

Cho, E.-K.., Han, S.-Y., Lee, H.-S., Lee, H.-R.; Kang, M.-J., \& Kim, J-J. (2011). Estimating the economic impacts on the region of Jirisan Trail. The Journal of Korea Institute of Forest Recreation, 15(1), 33-38.

Curtin, S. (2010). The self-presentation and selfdevelopment of serious wildlife tourists. International Journal of Tourism Research, 12(1), 17-33.

Davis, D., \& Tisdell, C. A. (1999). Tourist levies and willingness to pay for a whale shark experience. Tourism Economics, 5(2), 161-174

Eagles, P. F. J., \& Cascagnette, J. W. (1995). "Canadian Ecotourists: Who Are They?". Tourism Recreation Research, 20(1), 22-28.

Ekayani, M \& Nuva. (2013). Economics of Ecotourism. In: S. Kim, M. Kang, \& D. Sukmajaya(eds.), Opportunities and challenges of ecotourism in ASEAN countries (pp. 192- 215). Seoul: Jungmin Publishing Co.

Ekayani, M., Nuva, Yasmin, R.K., Shaffitri, L.R., \& Tampubolon, B.I. (2014). Taman nasional untuk siapa? Tantangan membangun wisata alam berbasis masyarakat di Taman Nasional Gunung Halimun Salak. Risalah Kebijakan Pertanian dan Lingkungan, 1(1), 46 - 52.

Gosken, F., Adaman, F., \& Zenginobuz, E.U. (2002). On environmental concern, willingness to pay, and postmaterialist values. Environment and Behaviour, 34(5), 616-633.

Jang, S. C., Morrison, A. M., \& O’Leary, J. T. (2002). Benefit segmentation of Japanese pleasure travelers to the USA and Canada: selecting target markets based on the profitability and risk of individual market segments. Tourism Management, 23(4), 367-378.

Jeong, A.-S., \& Park, Y.-C. (2003). An analysis on the development factors of green tourism - with special reference to the use value of recreation forests. The Journal of Korea Institute of Forest Recreation, 7(4), 31-40. 
Kahneman, D., Knetsch, J. L., \& Thaler, R. H. (1986). Fairness as a constraint on profit seeking: Entitlements in the market. The American Economic Review, 76(4), 728-741.

Kahneman, D., \& Knetsch, J. L. (1992). Valuing public goods: The purchase of moral satisfaction. Journal of Environmental Economics and Management, 22, 57-70.

Kraus, R.G. (1998). Recreation and leisure in modern society. Boston: Jones \& Bartlett Publishers, Inc.

Kristinawanti, I. (2014). Pengaruh pengembangan wisata alam Taman Wisata Alam Gunung Pancar terhadap perspektif sosial ekonomi. Bogor Agricultural University, Bogor.

Ku,K.-C., \& Chen, T.-C. (2013). A conceptual process-based reference model for collaboratively managing recreational scuba diving in Kenting National Park. Marine Policy, 39, 1-10.

Lee, C. K., Lee, J. H., Kim, T. K., \& Mjelde, J. W. (2010). Preferences and willingness to pay for bird-watching tour and interpretive services using a choice experiment. Journal of Sustainable Tourism, 18(5), 695-708.

Loureiro, M.L., \& Umberger, W.J., (2003). Estimating consumer willingness-to-pay for countryof-origin labeling. Journal of Agricultural and Resources Economic, 28, 287-301.

Maddala, G.S. (1983). Limited dependent and qualitative variables in econometrics. Cambridge: Cambridge University Press.

Mathieson, A., \& Wall, G. (1982). Tourism: economic, physical, and social impacts. London: Longman.

Nizar, M.A. (2015). Kelas menengah (middle class) danimplikasinya bagi perekonomian Indonesia. In Zuprianto (Eds.), Bunga rampai ekonomi keuangan (pp. 171-192). Jakarta: Nagakusuma Media Kreatif

Nowacki, M. (2013). Determinants of satisfaction of tourist attraction visitors. New Zealand: Active Poznan

Pagiola, S., Agostini, P., Gobbi, J., de Haan, C., \& Ibrahim, M. (2004). Paying for biodiversity conservation services in agricultural landscape. Washington DC: The World Bank.

Park, W.-S. (2010). A study on non-use valuation of recreation forest in the Nature Conservation Zone. Journal of the Korea Real Estate Society, 28(1), 151-173.

Pearce D., Atkinson G., \& Mourato, S. (2006).
Cost-benefit analysis and the environment: Recent development. Paris: OECD

Pizam, A. (1978). Tourism's impacts: The social costs to the destination community as perceived by its residents. Journal of Travel Research, 16(4), 8-12.

Pouta, E., Neuvonen, M., \& Sievänen, T. (2009). Participation in crosscountry skiing in Finland under climate change: application of multiple hierarchy stratification perspective. Journal of Leisure Research, 41(1), 91108.

Ramdas, M., \& Mohamed, B. (2014). Impacts of tourism on environmental attributes, environmental literacy and willingness to pay: A conceptual and theoretical review. Procedia - Social and Behavioral Science, 144 (2014), 378 $-391$

Reynisdottir, M., Song, H., \& Agrusa, J. (2008). Willingness to pay entrance fees to natural attractions: An Icelandic case study. Tourism Management, 29(6), 1076-1083.

Romsa, G., \& Blenman, M. (1989). Vacation patterns of the elderly German. Annals of Tourism Research, 16(2), 178-188.

Sim, Kyu-Won; Kwon, Heon-Gyo; Lee, SookHyang. (2013). A Study on economic value of national park based on contingent valuation methods - case of 20 national parks. The Journal of Korea Institute of Forest Recreation, 17(4), 33-40.

Stern, P. C. (2000). Toward a coherent theory of environmentally significant behavior. Journal of Social Issues, 56(3), 407-424.

Supriyanto, B., \& Sari, L. (2013). Ecotourism on National Parks in Indonesia. In Teguh, F., \&Avenzora, R. (Eds.), Ecotourism and sustainable tourism development in Indonesia: Potentials, lessons and best practices (pp. 34-63). Jakarta: Ministry of Tourism and Creative Economy Republic of Indonesia.

Szell, A. B., \& Hallet, Iv, L. F. (2013). Attitudes and perceptions of local residents and tourists toward the protected area of Retezat National Park. Romania Department of Geography, 3(3), 45-61.

Tisdell, C., \& Wilson, C. (2005). Perceived impacts of ecotourism on environmental learning and conservation: turtle watching as a case study. Environment, Development and Sustainability, 7(3), 291-302.

Tobin, J. (1958). Estimation of relationships for 
limited dependent variables. Econometrica.,26 (1) : 24-36

Togridou, A., Hovardas, T., \& Pantis, J.D. (2006). Determinants of visitors' willingness to pay for the National Marine Park of Zakynthos, Greece. Ecological Economics, 60(1), 308-319

Uyarra, M.C., Côté, I.M., Gill, J.a., Tinch, R.R.T., Viner, D., \& Watkinson, A.R. (2005). Island-specific preferences of tourists for environmental features: implications of climate change for tourism-dependent states. Environmental Conservation, 32(1), 11-19.

Villalobos-Céspedes, D., Galdeano-Gómez, E., \& Tolón-Becerra, A. (2012). International demand for nature-based tourism in Costa Rica: Sociodemographic and travel indicators. Tourismos, 7(1).

Wagner, T.H., Hu T-W., \& Dueńas G.V. (2000). Willingness to pay for mammography: item development and testing among five ethnic groups. Health Policy, 53, 105-21

Wang, P.-W., \& Jia, J.-B. (2012). Tourists' willingness to pay for biodiversity conservation and environment protection, Dalai Lake protected area: Implications for entrance fee and sustainable management. Ocean \& Coastal Management, 62, 24-33. 